\title{
The Effect of Shopping Life Style and Positive Emotion on Buying Impulse
} (Case Study of the Palembang City Hypermarket)

\author{
Ahmad Maulana ${ }^{1}$, Mukhlis ${ }^{2}$, Nurkardina Novalia ${ }^{3}$ \\ 1,2Sriwijaya University, Palembang, South Sumatra, Indonesia \\ IBBA University, Palembang, South Sumatra, Indonesia \\ maulanaahmad075@gmail.com
}

\begin{abstract}
This study aims to determine: (1) the effect of Shopping Life Style on impulse buying on customers at Palembang City Hypermarket, (2) the effect of positive emotions on Impulse buying on customers at Palembang City Hypermarket, (3) the effect of Shopping Life Style and positive emotions impulse buying for customers at the Palembang City Hypermarket. This study uses primary data obtained by survey methods by distributing questionnaires that have been tested for validity and reliability. The population in this study were customers at the Palembang City Hypermarket. The sampling technique used purposive sampling method with a total sample of 150 people. The data analysis technique used is path analysis. Shopping LifeStyle has a significant effect on the Hypermarket impulse buying in Palembang. Positive emotions have a significant effect on Impulse Buying at Hypermarket consumers in Palembang.
\end{abstract}

Keyword: Shopping Life Style, Positive Emotion, Impulse Buying.

\section{Introduction}

Today's consumer needs are constantly changing, which greatly influences changes in lifestyle or lifestyle patterns. Along with changes in lifestyle, consumers will always try to meet their needs. Consumer behavior to meet their needs will be related to consumer shopping behavior. Consumer shopping behavior will arise due to the existence of planning or without prior planning (impulse buying). Consumers as purchasing decision-makers or those who influence the decision-making process need to be understood in order to create the Impulse Buying phenomenon to increase sales. To be able to bring up the impulse buying phenomenon, marketers must know the factors that influence consumers in doing impulse buying. The causes of impulse buying include excessive consumption and positive emotions (Amiri et al., 2012). At present most consumers in Indonesia are more recreation oriented when shopping (Ma'ruf, 2006). Shopping Life Style includes behavioral aspects related to multi-sensory, fantasy and emotional consumption that are controlled by benefits such as pleasure in using products and aesthetic approaches. According to Hausman (2000), the value of hedonic shopping plays an important role in impulse buying. Along with the development of Palembang City as one of the big cities and is expected to develop into a "Metropolitan" city, the existence of a comfortable and modern economy means a necessity for city residents and tourists who visit. Following the demands of these needs, in the city of Palembang also grew and developed one of them Hypermarkets.

Hypermarket is a shopping center with one or several large department stores as the attraction of small retailers and restaurants with building typologies such as shops facing the main hypermarket or pedestrian corridors which are the main elements of a shopping center (hypermarket), with functions as circulation and as a communal space for the implementation of interactions between visitors and traders (Maitland, 1987). The rapid development of this hypermarket has an impact on human behavior. At this time in human behavior there has been a shift in behavior (behavior change). The behavior of people who plan shopping becomes unplanned or impulse buying. This situation is seen in the situation of hypermarkets that provide goods that can meet their needs (consumers) and provide benefits to them financially. They forget the purpose when they enter the store as they should. This phenomenon occurs at the Hypermarket of Palembang City which provides many outlets in it and offers various consumer goods. Based on the results of pre survey observations, researchers can conclude that lifestyle is very influencing consumer thinking patterns about meeting their needs. Consumers with a shopping lifestyle will tend to be happy with everything that is luxurious without thinking about prices and budgets, including in this case the purchase of fashion products. Based on the results of observations of researchers, it shows that consumers are very easy to spend money to shop, usually will often make purchases outside of what they planned before. 


\section{Literature Review}

Consumer Behavior: An understanding of consumer behavior and the consumption process will result in a number of benefits including helping managers in making decisions, providing basic knowledge for researchers in analyzing consumers, and helping consumers make better purchasing decisions (Mowen in Dwiastuti, et al., 2012). Consumer behavior is the buying behavior of end consumers, both individuals and households, who buy products and services for personal consumption (Kotler and Armstrong, 2012). Consumer behavior is an action that is directly involved in obtaining, consuming, and consuming products and services, including the decision process that precedes and follows these actions (Engel et al., In Simamora, 2008).

Impulse Buying: According to impulse buying (impulse buying) is the process of buying an item, where the buyer does not have the intention to buy beforehand, it can be said that the purchase is without a plan or instant purchase. Meanwhile, according to Mowen and Minor (2002), impulse purchase (impulse purchase) is an act of buying that was not previously recognized consciously as a result of consideration, or intention to buy formed before entering the store. Clarified by the opinion of Rook and Fisher (1995) that impulsive buying is interpreted as the tendency of consumers to buy spontaneously, reflexively, suddenly, and automatically. It can be said that impulse buying is a natural thing and is a fast reaction.Sutisna (2002) explains that impulsive purchases occur when consumers make sudden purchasing decisions. The drive to make purchases is so strong that consumers no longer think rationally about their purchases. According to Park (2007), impulsive purchases often appear suddenly, quickly, spontaneously, more emotionally than rationally, more often regarded as something bad than something good, and consumers tend to feel "outofcontrol" when buying goods impulsively. In line with the opinion expressed by Schiffman and Kanuk (2007) that impulsive buying is an emotional decision or according to the insistence of the heart. Emotions can be very strong and act as the basis of the dominant buying motive.

Shopping Lifestyle: Lifestyle refers to how a person lives, how they spend their time and money, purchasing activities they do, their attitudes and opinions about the world in which they live (Kotler and Keller, 2012). A person's lifestyle can be shown by looking at his opinion on a particular object. A person's lifestyle is a pattern of life in the world expressed by one's activities, interests, and income. Shopping lifestyle is defined as the behavior shown by customers in connection with a series of personal responses and opinions about product purchases (Tirmizi, 2009). The way we shop reflects status, dignity and habits. Shopping lifestyle shows the way someone chooses to allocate income, both in terms of fund allocation for various products and services, and certain alternatives in differentiating similar categories (Zablocki and Kanter in Japarianto 2010).

Positive Emotions: Emotions which include feelings and mood (mood) are important factors in making decisions by consumers (Park, Kim, \& Forney, 2007). Emotions can be divided into two dimensions, namely positive and negative. Positive emotions can be seen through positive feelings such as pleasure, love, liking, enjoyment, satisfaction, and alertness. The creation of positive emotion for consumers regarding a product or article or even a store environment can increase the motives of consumers in doing impulse buying. According to Peter and Olson (2005) states that the main store atmosphere involves affection in the form of emotions in a store that may be completely unnoticed by customers when shopping. The basic model underlying Donovan and Rositter's research, shown in Figure 1, was taken from the environmental, psychological literature. Basically, the model states that environmental stimulation influences the customer's emotional status, which in turn affects behavior or becomes a customer. Approaching behavior is a movement towards and avoidance behavior is a movement away from various kinds of environments and stimuli. 


\section{Figure 1: Framework of Thinking}

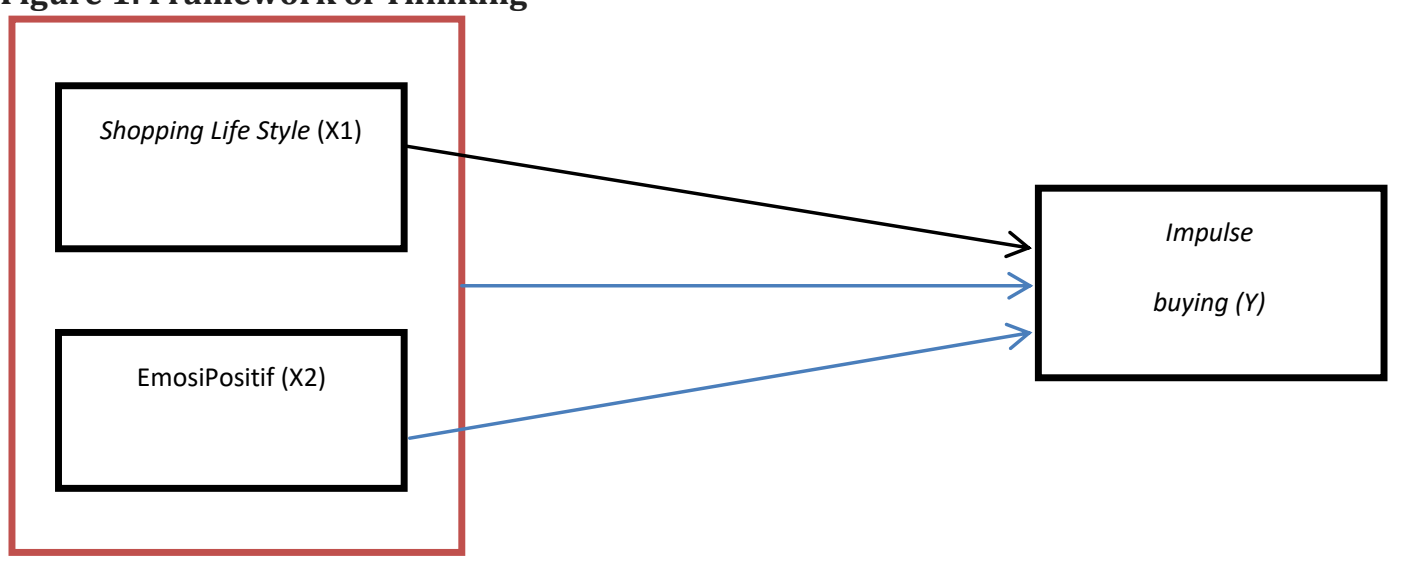

\section{Methods}

This study uses multiple linear regression analysis techniques, to test whether there is a relationship between independent variables Shopping Life Style $\left(\mathrm{x}_{1}\right)$, Positive Emotions $\left(\mathrm{x}_{2}\right)$, with independent variables Impulse Buying (Y).

The regression equation in this study is as follows:

$Y=a+\beta_{1} X_{1}+\beta_{2} X_{2}+e$

Information :

a $\quad=$ Constanta

$\beta_{1} \beta_{2}=$ Variable Regression Coefficient $X_{1}$ and $X_{2}$

$\mathrm{X}_{1} \quad=$ Life Style

$\mathrm{X}_{2} \quad=$ Positive Emotions

$\mathrm{Y} \quad=$ Impulse Buying

$e \quad=$ Standard error

\section{Results}

\section{Classic Assumption Test}

Multicollinearity Test: The regression model does not experience multicollinearity disorders. This can be seen in the tolerance value of each variable greater than 10 percent (0.1). The VIF calculation results also show that the VIF value of each variable is less than 10 . So it can be concluded that there is no multicollinearity between the independent variables in the regression model.

Table 1: Uji Multikolinearitas

\section{Collinearity Statistic}

\begin{tabular}{lll}
\hline Variables & Toleran & VIF \\
\hline Shopping Life Style & 0,960 & 1,041 \\
Positive emotions & 0,960 & 1,041 \\
\hline
\end{tabular}

Heteroscedasticity Test: The scatterplot graph does not have a clear spread pattern and the points spread above and below the number 0 on the Y-axis. This shows that there is no heteroscedasticity disturbance in the regression model. 
Figure 1: Heteroscedasticity Test

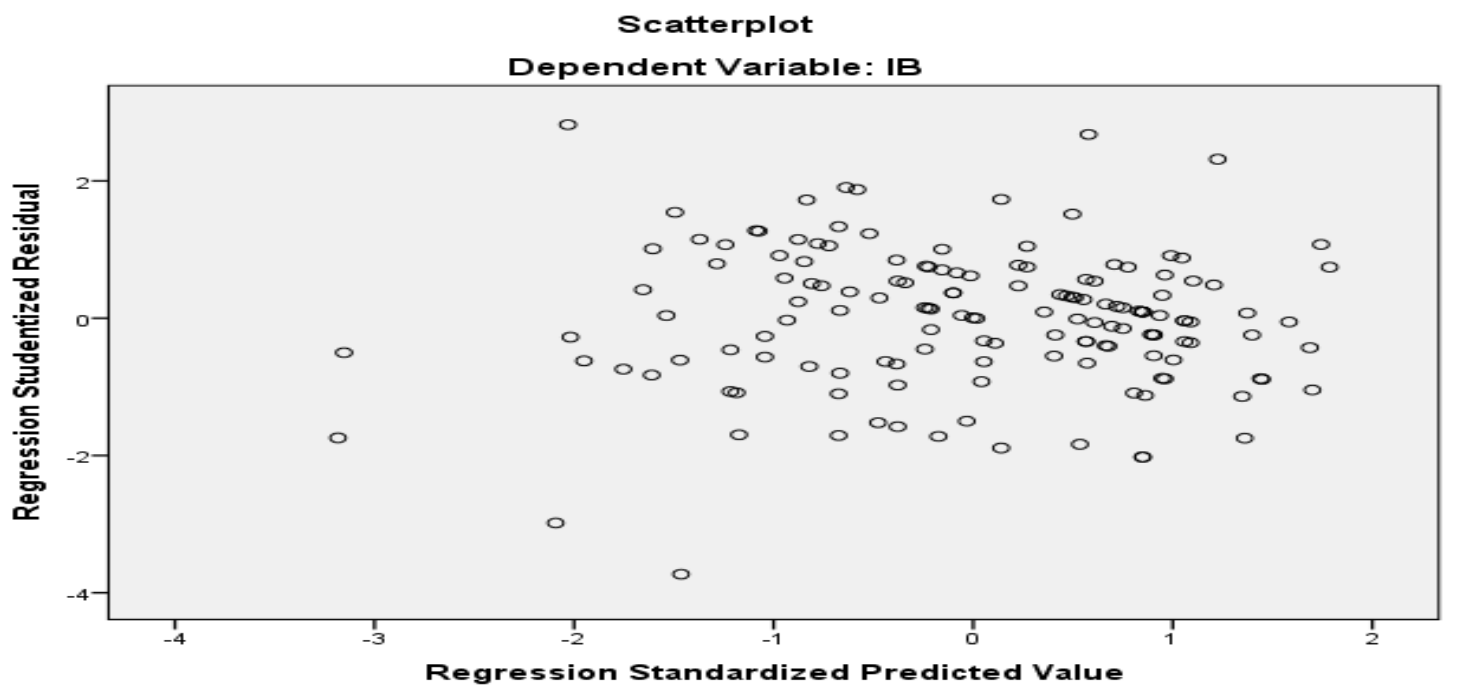

Normality Test: The normal probability plot graph shows a normal graph pattern. This can be seen from the point that spreads around the normal graph. This can be seen from the points that spread around the diagonal line and the spread follows the diagonal line. Therefore, it can be concluded that the regression model is feasible because it meets the assumptions of normality.

Figure 2: Normality Test

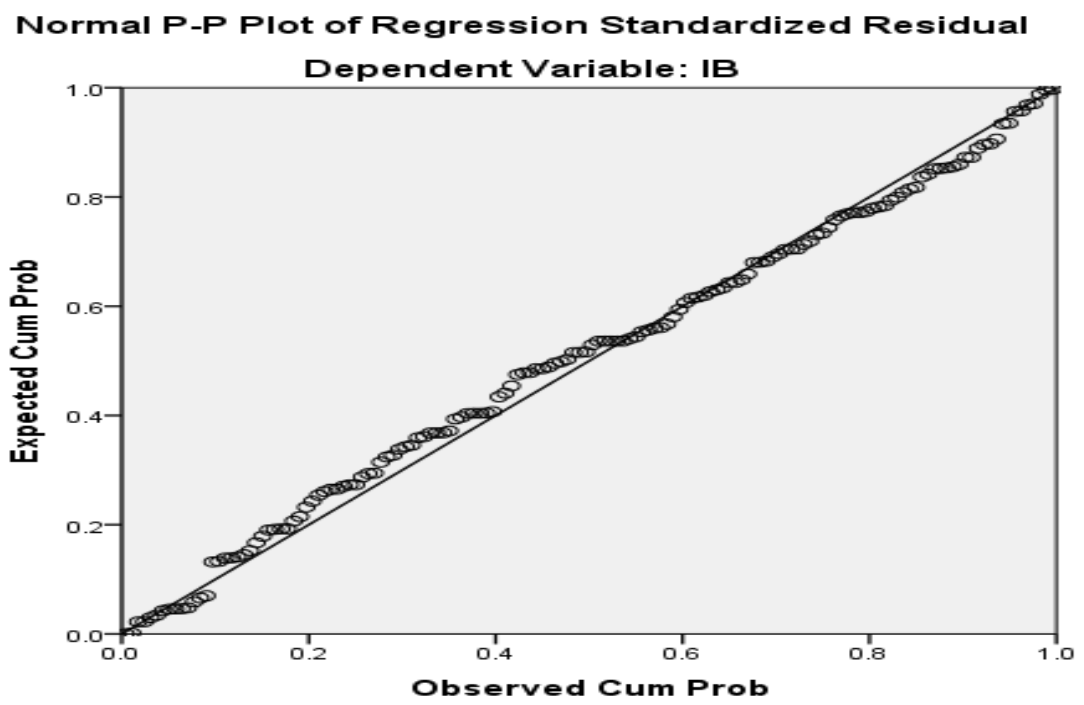

\section{Autocorrelation Test}

Table 2: Autocorrelation Test

\begin{tabular}{ll}
\hline Variable & Significant Value \\
\hline Durbin Watson & 1,303 \\
\hline
\end{tabular}

The Durbin Watson value is between -2 to 2, meaning that there is no autocorrelation problem (Santoso, 2012). 


\title{
Test Results T
}

Table 3: Test Results T

\section{Test Result}

Variable

Significant

Shopping LifeStyle

Positive Emotions

\author{
0.000
}

0.000

In shopping Life Style variables with a significance level of 95\% ( $\alpha=0.05)$. The significance value (P Value) in the LifeStyle shopping variable is $0.003<0.05$. On the basis of these comparisons, H0 is rejected or means that the LifeStyle shopping variable has a significant influence on the Impulse Buying variable. Positive Emotion variables with a significance level of $95 \%(\alpha=0.05)$. The number of significance (P Value) in the variable is $0.440>0.05$. On the basis of these comparisons, HO is accepted or means the Positive Emotion variable does not have a significant effect on the Impulse Buying variable.

\section{Simultaneous Test (F Test)}

Table 4: F Test

\begin{tabular}{|c|c|c|c|c|c|c|}
\hline \multicolumn{2}{|c|}{ Model } & \multirow{2}{*}{$\begin{array}{l}\text { Sum of Squares } \\
608.750\end{array}$} & \multirow{2}{*}{$\begin{array}{l}\mathbf{D F} \\
2\end{array}$} & \multirow{2}{*}{$\begin{array}{l}\text { Mean Square } \\
304.375\end{array}$} & \multirow{2}{*}{$\begin{array}{l}\text { F } \\
27.447\end{array}$} & \multirow{2}{*}{$\begin{array}{r}\text { Sig. } \\
.000\end{array}$} \\
\hline 1 & Regression & & & & & \\
\hline & Residual & 1630.190 & 147 & 11.090 & & \\
\hline & Total & 2238.940 & 149 & & & \\
\hline
\end{tabular}

From the results of the $\mathrm{F}$ test in this study, the calculated $\mathrm{F}$ value is 11,186 with a significant number (P value) of 0,000 . With a significance level of $95 \%(\alpha=0.05)$. The number of significance (P value) is $0,000<0,05$. On the basis of these comparisons, HO is rejected or means that the variable Shopping Life Style and Positive Emotion have a jointly significant effect on the Impulse Buying variable.

\section{Coefficient of Determination}

Table 5: Coefficient of Determination

Adjusted R Square

\begin{tabular}{lllll} 
Model & $\mathbf{R}$ & R Square & Estimate \\
\hline 1 & $.521^{\mathrm{a}}$ & .272 & .262 & 3.330
\end{tabular}

In table 5 it can be seen that the adjusted R2 value is 0.26 . This can be interpreted that the independent variable (Shopping Life Style and Positive Emotion) can explain the dependent variable (Impulse Buying) of $26 \%$, while the rest is explained by other factors not examined. 


\section{Regression Coefficient}

Table 6: Regression Coefficient

Standardized
Coefficients

Unstandardized Coefficients

\begin{tabular}{|c|c|c|c|c|c|c|c|c|}
\hline \multirow{2}{*}{\multicolumn{2}{|c|}{ Model }} & \multicolumn{5}{|c|}{ Unstandardized } & \multicolumn{2}{|l|}{ Collinearity } \\
\hline & & B & Std. Error & Beta & $\mathbf{t}$ & Sig. & Tolerance & VIF \\
\hline \multirow[t]{3}{*}{1} & (Constant) & 11.805 & 2.481 & & 4.758 & .000 & & \\
\hline & SL & .199 & .041 & .347 & 4.836 & .000 & .960 & 1.041 \\
\hline & EP & .287 & .063 & .326 & 4.539 & .000 & .960 & 1.041 \\
\hline
\end{tabular}

Based on table 6, we find the multiple linear regression equation as follows:

$\mathrm{Y}=\mathbf{1 1 , 8 0 5}+\mathbf{0 , 1 1 9} \mathrm{X1}+\mathbf{0 , 2 8 7} \mathrm{X} 2$

The above equation can be explained as follows:

- The value of 0.119 in the Shopping Life Style (X1) variable is positive so that it can be said that the higher the Shopping Life Style given by the Consumer, the higher the Impulse Buying will be.

- The value of 0.287 on the Positive Emotion variable (X2) is positive so that it can be said that the higher the Positive Emotions provided by the Consumer, the higher the Impulse Buying will be.

\section{Conclusion}

Based on the analysis and discussion of the influence of shopping lifestyle variables on impulse buying through positive emotions in consumers of the Palembang hypermarket, conclusions can be drawn as follows:

- Shopping Life Style significantly influences the Hypermarket impulse buying in Palembang.

- Positive Emotions significantly influence Impulse Buying at Hypermarket consumers in Palembang.

\section{References}

Amiri, F., Jalal, J., Mohsen, S. \& Tohid, A. (2012). Evaluation of Effective Fashionism Involvement Factors on Impulse Buying of Costumers and Condition of Interrelation between these Factor. Journal of Basic and Applied Scientific Research, 2(9), 9413-9419.

Dwiastuti, R., Shinta, A. \& dan Isaskar, R. (2012). Ilmu Perilaku Konsumen. Malang: Universitas Brawijaya Press.

Hausman, Angela. (2000). A Multi-Method Investigation of Consumers in Impulse Buying Behavior. Journal of Consumer Marketing, 17(5), 403-426.

Japarianto, Edwin. (2010). Analisa Faktor Type Hedonic Shopping Motivation dan Faktor Pembentuk Kepuasan Tourist Shopper di Surabaya. Jurnal Manajemen dan Kewirausahaan, 12(1), 76-85.

Kotler, P. \& dan Armstrong, G. (2012). Principles of Marketing. New Jersey: Prentice-Hall, Inc.

Kotler, P. \& dan Keller, K. L. (2012). Marketing Management. New Jersey: Pearson Education, Inc.

Maitland, Barry. (1987). Shopping Hypermarkets Planning and Design. London: Construction Press.

Ma'ruf, Hendri. (2006). Pemasaran Ritel. Gramedia Pustaka Utama : Jakarta.

Mowen, Jonh, C. \& Minor, Michael. (2002). Perilaku Konsumen Jilid 1. Alih Bahasa: Lina Salim. Jakarta: Erlangga.

Park, J. S., Shin, K. H., Park, J. B., Lee, S. \& dan Hwang, S. J. (2007). Disintegrating Behaviour of A Rapidly Disintegrating Famotidine Tablet Formulation. J. Kor. Pharm. Sci, 37(5), 275-280.

Peter, J. \& Paul dan Olson Jerry, C. (2005).Consumer Behavior and Marketing Strategy,5th,Singapore, The Mc, Graw Hill Companies,Inc 
Rook, D. W. \& Fisher, R. J. (1995). Normative Influences on Impulsive Buying. Journal of Consumer Research, 22, 305-313.

Santoso, Singgih. (2012). Panduan Lengkap SPSS Versi 20. Jakarta: PT Elex Media Komputindo.

Schiffman, L. G. \& Kanuk Leslie, L. (2007). Consumer Behavior. America: Pearson Prentice Hall.

Simamora, B. (2008). PanduanRisetPerilakuKonsumen. Jakarta: PT GramediaPustakaUtama.

Sutisna. (2002). Perilaku Konsumen dan Komunikasi Pemasaran. Bandung: PT Remaja Rosdakarya.

Tirmizi, M. A. (2009). An Empirical Study of Consumer Impulse Buying Behaviour in Local Markets. European Journal of Scientific Research, 28(4), 522-532. 